\title{
Teaching Reform of Exercitation Course of Electronic Technology under the Background of Innovation and Entrepreneurship Education
}

\author{
Ji-Hai Liao ${ }^{1}$, Juan Shi ${ }^{2 *}, \mathrm{Li}^{-X i u ~} \mathrm{Li}^{1}$ \\ ${ }^{1}$ School of Physics and Optoelectronics, South China University of Technology, Guangzhou, China; \\ ${ }^{2}$ Center of Educational Technology of Teaching Affairs Office, South China University of Technology, \\ Guangzhou, China \\ *Corresponding author
}

Keywords: Innovation; Entrepreneurship; Electronic technology; Teaching reform.

Abstract. The purpose of present teaching reform was to enhance the innovation and entrepreneurial ability of college students. We took the concept of innovation and entrepreneurship education and of the OBE education model throughout the electronic technology practice process. We introduced new practice contents, such as PSOC3 system, 3D printers and intelligent robots. As for teaching methods, we have videoed a series of micro-courses and put the teaching resources on the We-Chat public platform, facilitating fragmentary learning anytime and anywhere. We implemented the internship mode of school-enterprise cooperation as well as combination of competition and teaching. As for course grades, we took innovative and entrepreneurial elements into account. The series of teaching reforms effectively enhanced the consciousness of innovation and entrepreneurship.

\section{Introduction}

As the development of Chinese economy and society has reached a new level, the Party Central Committee and the State Council have made important decisions to accelerate the implementation of innovation-driven development strategies and the construction of innovative countries. Considering such an environment, it has become the consensus of the central government and universities to carry out the innovation and entrepreneurship education reform comprehensively and thoroughly. South China University of Technology (SCUT) has become one of the first universities to deepen reform of innovation and entrepreneurship education in China. In order to implement the spirit of the "Implementation Suggestions of the General Office of the State Council on Deepening the Reform of Innovation and Entrepreneurship Education in Colleges and Universities” (No. 36, issued by the State Office of the People's Republic of China) and promote the reform of innovation and entrepreneurship education, carrying out the research and practice on the teaching reform of exercitation course of electronic technology integrating innovation and entrepreneurship education is of importantly theoretical and practical significance.

The exercitation course of electronic technology is a public basic practice course with a wide range of benefits. There are more than 2,000 undergraduate students majoring in science and engineering who participate in this course every year. This research will help to cultivate the innovative and entrepreneurial ability of college students in our university. On the other hand, through the demonstration of the relevant research results, it will help to improve the quality and level of innovation and entrepreneurship education in Guangzhou, Guangdong and even the whole country's universities.

This research relies on the "Undergraduate Deep Reform Project" of the Ministry of Education and the Electronic Technology Experimental Teaching Center of the Experimental Teaching Demonstration Center of Guangdong Higher Education, etc. Meanwhile, it is based on the electronic technology innovation and entrepreneurship training base and use modern information technology as a technical support to do research and practice on the teaching reform of exercitation course of electronic technology. Besides, it integrates the concept of innovation and entrepreneurship education, implementing the core concept of the OBE education model. The specific research framework is shown in Fig. 1. 


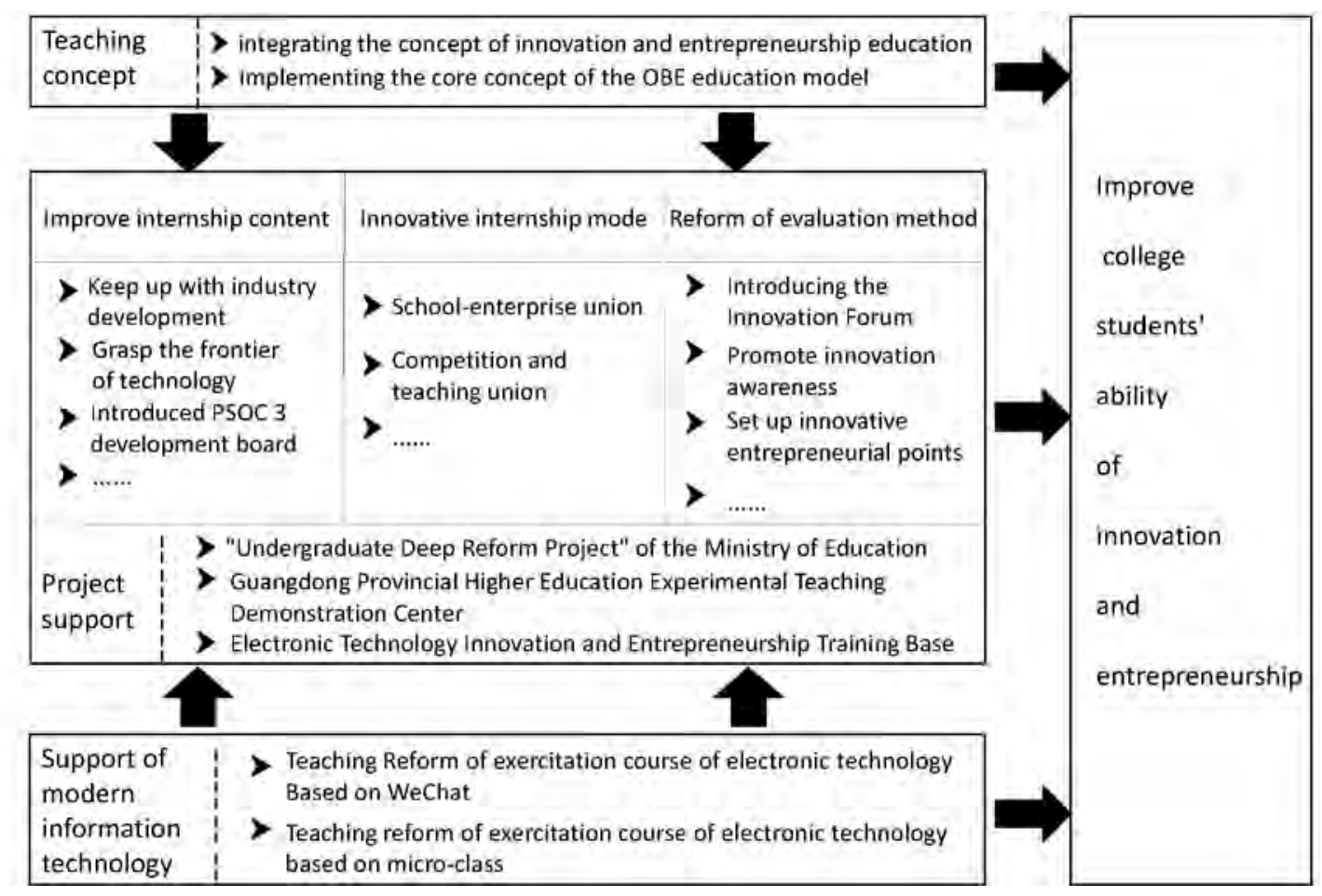

Fig.1 Research framework of the teaching reform

\section{Reform of Teaching Concept}

\subsection{Integrating the concept of innovation and entrepreneurship education}

In order to integrate the concept of innovation and entrepreneurship education into practical teaching process, the teaching staffs of this course received systematic training about innovation and entrepreneurship education concept. There are twelve teaching staffs in the Electronic Technology Training Center, eight of whom have senior titles. We taught the public basic course "Electronic Technology internship" with the class hours times participants beyond 100,000 per year. If the teachers themselves are lack of the concept of innovation and entrepreneurship education, the integration of professional courses innovation and entrepreneurship education will become an empty talk. Therefore, improving the innovation and entrepreneurial quality of professional course teachers is the fundamental measure to integrate innovative entrepreneurial education into the course. We invited some professors, who have rich experience in innovative practice and entrepreneurial management, from the School of Entrepreneurship Education or other organizations to give series of lectures about "innovation and entrepreneurship education" for the teaching staffs, to enhance our innovative and entrepreneurial literacy.

\subsection{Implementing the core concept of the OBE education model}

The core concepts of the OBE education model are: "Student Center", "Results Orientation”, and "Continuous Improvement" ${ }^{[1]}$. Since all the internship programs and time in the traditional mode of electronic technology practice are fixed, it is not conducive to the students' autonomy, because all the students including those who have good foundation do the same exercises. In this mode, students can only be passively accepted to complete a course, and the concept of student-centered and results-oriented cannot be reflected. For some students with better foundations, as well as from the excellent classes and innovation classes, they can be accepted to adopt an open internship mode. The open teaching model advocates "project-oriented" ,which may include: "small team project", “engineering innovation cooperation project”, “design competition project”, “design project for enterprises”, etc. ${ }^{[2]}$. Formally, we can adopt various methods such as content opening, time opening, examination opening, and so on. Some students who already have the basic knowledge of electronic technology and have certain experience in electronic design and production can follow the form of the national electronic design competition, and 
gather another two or three students to form a project team. After freely combining, they work out the project name by themselves. The project can be oriented to the teaching and research group, engineering, competition, or enterprise. The students complete the creative conception, structural design, process arrangement, production and processing, summary report and on-site reply under the guidance of teachers. This model combines the content of practical courses with project research, merging in-class and extra-curricular, guiding students to participate in scientific research.

\section{Reform of Teaching Contents and Methods}

\subsection{Reform of teaching contents}

The content of the course needs to keep up with the development of the industry, grasp the development direction of electronic technology, and make use of the advanced mainstream technology to build complex electronic system in a simple way. Nowadays, complex system-level design is a direction of the development of electronic products [3], and designing a system with separate components and processes is too complicated and costs a long cycle. We can introduce system-level design for teaching in the electronic process internship. This study introduces the successful PSOC3 development board developed by Tsinghua University, allowing students to use the PSOC3 development board for system design. The PSOC core adopts the chip produced by Cypress Company, which realizes the high integration of MCU, digital system and analog system on a single chip. It makes the design more flexible, greatly saves the design cost, reduces the design overhead, and conforms to the trend of the future development of electronic technology. Meanwhile, when designing the system, students are admitted to voluntarily design and complete the project which they are interested in according to the basic conditions of the system. Consequently, the students can bring their subjective initiative into play, instead of seeking to be the same as others passively.

As for the tasks of internship, we bring in new types of electronic products such as 3D printers, drones and intelligent robots in the open internship mode to fully inspire students' enthusiasm for innovation and entrepreneurship. These electronic products have some formed modules. During the internship process, we focus on guiding students to improve and innovate on existing basis.

\subsection{Reform of teaching methods}

This research is about the reform of teaching methods of exercitation course of electronic technology, including reform based on We-Chat, micro-courses and so on. The reform of the teaching pattern of the exercitation course of electronic technology based on We-Chat is mainly through building the We-Chat public platform named Electronic Technology Center of SCUT, transplants the teaching resources from original website of teaching center to the We-Chat public platform. Also, we rely on the platform to release the seating chart, internship arrangement, internship progress, report cards and so on. It can also be used to optimize network teaching materials, improve the test database, establish a troubleshooting database, and explore new electronic technology practice teaching mode ${ }^{[4]}$.

Mainly aimed at teaching program and content of the course, the reform of exercitation course of electronic technology based on micro-courses carefully choose appropriate teaching knowledge points, and make use of modern information technology, elaborately make a series of high-quality electronic technology internship micro-courses. What's more, we take advantage of multimedia to demonstrate advanced technology of electronic component making, testing, packaging and assembling. We also carry out the innovation of the electronic course practice teaching mode base on micro-courses, teaching students in accordance with their aptitude and in different levels, so as to promote the individualized development of students and enhance their innovative spirit and practical ability ${ }^{[5]}$.

\section{Reform of Teaching Pattern}

\subsection{Innovating the teaching pattern of the course with college-enterprise coalition}

Teaching pattern of exercitation course of electronic technology on innovative college-enterprise joint mainly makes use of abundant social resources, invites engineering and technical personnel in enterprise 
to teach our students or guide their innovation. This new model can solve the problems and contradictions in the past electronic technology internship, promote students to better combine theory and practice. Besides, it can mobilize student' learning enthusiasm, and accelerate students' capacity training for innovation and entrepreneurship ${ }^{[6]}$.

During the course, we arranged course contents in the form of visiting and studying in enterprises. Electronic technology practice center keep in close touch with many companies, such as Guangzhou Taihe Circuit Board Co., LTD, Guangzhou Jingliang Circuit Board Co., LTD, and Guangzhou Xinke Sound Co., LTD. We arranged students to go to the enterprise to inspect the operation of the company and prepare for the business.

\subsection{Innovating a new teaching pattern of combining competition and education}

We carried out teaching reform based on "the combination of competition and education", promoted the reform of teaching content through competition, and guided college students not only to learn and continuously expand their knowledge, but also to constantly innovate in their learning process. We proposed new problems and solved them. During the competition, students were able to learn planning and coordinating, strengthen the communication with the members of the project and other personnel, improve their communication skills and teamwork ability, and then comprehensively enhanced their practical ability and innovation and entrepreneurial ability ${ }^{[7]}$.In addition, patent agents were invited to guide the innovation of the competition team's technical solutions and patent mining, and document the innovative technology in the competition by means of intellectual property.

Based on the establishment of the electronic technology innovation and entrepreneurship training base, we held the first and second “Electronic Technology Innovation Design Competition” in 2016 and 2017 with more than 200 participants. At present, we are organizing the third competition. Relying on the competition, we hope to create a good atmosphere for innovation and entrepreneurship in our campus.

\section{Reform of Teaching Evaluation}

An important part of the educational process is to evaluate students. The developmental function of evaluation embodies the educational philosophy of "all for the development of students". The development of students requires goals, guidance and motivation. However, the traditional student evaluation emphasizes the subject knowledge system and practical skills too much, neglects the humanity and restricts the development of students' comprehensive ability. The significance of innovation and entrepreneurship education is to promote students to improve their quality and ability of innovation and entrepreneurship, and to guide their continuous development and improvement. In the assessment method of electronic technology internship, it is necessary to observe, and evaluate students through the attention and participation status of students, encourage them to devote themselves to learning in the classroom, and experience feelings like satisfaction, success and joy through the production practice of electronic products. Thus, they will be more interested in follow-up learning and practice, and further inspire their confidence in innovation and entrepreneurship.

In the traditional electronic process assessment method, theoretical examinations account for $30 \%$. Moreover, usual grades including attendance, practical skills, and internship reports account for $70 \%$. It highlights the importance of the practical skills of the course. In the new format, we intend to incorporate innovative and entrepreneurial elements into the curriculum assessment. For the traditional internship mode, firstly, we introduce an electronic product innovation forum in the course, and guide students to propose a new electronic product concept with their imagination, and the students who share their ideas can get grades of innovation. Secondly, we require students to add the part of conception of innovation and entrepreneurship into their internship reports. As for the assessment mode of the open internship mode, the measure is to formulate project evaluation methods. Students must submit their project results-including market research reports, prototypes, summary papers, and product technical parameter documents. The grades of the open internship model were divided three parts: (1) the result of the project debugging and prototype (40\% of the total score); (2) the oral defense of the project results (40\%, of 
which "innovative" accounted for 10\% and "Entrepreneurial awareness" accounted for 10\%); (3) Project summary report (20\%).

\section{Conclusion}

In summary, we effectively introduce the concept of innovation and entrepreneurship education into the teaching of exercitation course of electronic technology, and promote the deep integration of innovation and entrepreneurship education and professional education, which can effectively enhance the innovation and entrepreneurial ability of college students. Based on the concept of innovation and entrepreneurship education, this research applies modern information technology, carries out the teaching reform of exercitation course of electronic technology based on We-Chat and micro-courses, innovates the internship mode of school-enterprise cooperation as well as combination of competition and teaching. What's more, we integrate innovative and entrepreneurial elements into the curriculum assessment to promote students' spirit of innovation, entrepreneurial thinking, and practical ability.

\section{Acknowledgments}

This work was supported by Education and Teaching Reform Project of Guangdong Province in 2016 (Grant No. 2016052), Guangdong Laboratory Research Funds (Grant No. GDJ2016019), Education Reform Project of SCUT in 2016 (Grant No. j2jw-Y9160780), Exploratory Experiment Project of SCUT in 2016 (Grant No. x2wl-Y1160420), and Guangzhou Innovation and Entrepreneurship Education Project for Universities in 2018 (Grant No. 201709K31).

\section{References}

[1]. Xu Xuefeng, Exploration of the teaching mode of the roadway engineering course based on the OBE concept [J]. Education Teaching Forum, vol.31, pp. 117-118, 2016. (In Chinese)

[2]. Liao Jihai, Li Lixiu, Zhang Cunfang, Fu Yuhe, Yang Rifu, Research-teaching reform of the electronic process course based on OBE [J]. Experimental Science and Technology, vol.15 (4), pp. 72-75, 2017.

[3]. Jin Guangzao, Modeling and Analysis of Complex System Reliability [M]. Beijing: National Defence Industry Press, 2015. (In Chinese)

[4]. Zhang Li, Sun Jian, College course teaching reform based on WeChat official accounts-taking “analog electronic technology” course as an example [J]. Electronic Test, pp.84-85, Oct. 2017.

[5]. Wang Jiliang, Research on course teaching reform based on Micro-Class [J]. Industry and Information Technology Education, pp.79-82, Apr. 2015. (In Chinese)

[6]. Mu Zaiquan, Li Taixu, Construction of school-enterprise joint training base [J]. China Steel Focus, pp. 51-55, Sep. 2016. (In Chinese)

[7]. Liu Dong, Zhu Zi-jiang, Deng Xiao-guang, Research on student's practical and creative ability based on combination of competitions and teaching [J]. Modern Computer, vol.34, pp. 8-10, 2012. 